\title{
Seasonal diet pattern of non-native tubenose goby (Proterorhinus semilunaris) in a lowland reservoir (Mušov, Czech Republic)
}

\author{
Z. Adámek ${ }^{(1)}$, P. Jurajda ${ }^{(2)}$, V. Prášek ${ }^{(2)}$, I. Sukop ${ }^{(3)}$ \\ Received March 18, 2010 / Reçu le 18 mars 2010 \\ Revised May 21, 2010 / Révisé le 21 mai 2010 \\ Accepted June 3rd, 2010 / Accepté le 3 juin 2010
}

Key-words: Gobiidae, food, lowland reservoir, rip-rap bank, the Dyje River

\section{ABSTRACT}

The tubenose goby (Proterorhinus semilunaris) is a gobiid species currently extending its area of distribution in Central Europe. The objective of the study was to evaluate the annual pattern of its feeding habits in the newly colonised habitats of the Mušov reservoir on the Dyje River (the Danube basin, Czech Republic) with respect to natural food resources. In the reservoir, tubenose goby has established a numerous population, densely colonising stony rip-rap banks. Its diet was exclusively of animal origin with significant dominance of and preference for two food items - chironomid (Chironomidae) larvae and waterlouse (Asellus aquaticus), which contributed 40.2 and $27.6 \%$, respectively, to the total food bulk ingested. The index of preponderance for the two items was also very high, amounting to 73.8 and 26.5 , respectively. In the annual pattern, a remarkable preference for chironomid larvae was recorded in the summer period whilst waterlouse were consumed predominantly in winter months. The proportion of other food items was rather marginal - only corixids, copepods, ceratopogonids and cladocerans were of certain minor importance with proportions of 5.4, 4.3, 4.1 and $3.9 \%$, respectively. Certain signs of cannibalism were also recorded, with 0.9 and $0.2 \%$ of the diet consisting of their own progeny and eggs, respectively.

\section{RÉSUMÉ}

Schéma saisonnier de l'alimentation du gobie demi-lune (Proterorhinus semilunaris) non-natif dans le réservoir de plaine Mušov (République tchèque)
Mots-clés :
Gobiidae,
alimentation,
Le gobie demi-lune (Proterorhinus semilunaris) est une espèce de gobie aug- mentant actuellement son aire de distribution à l'Europe Centrale. L'objectif de cette étude était d'évaluer le schéma annuel de l'alimentation dans des habitats nouvellement colonisés du réservoir Mušov sur la rivière Dyje (Bassin du Danube, réservoir de plaine, berges enrochées, Rivière Dyje République tchèque) par rapport aux ressources nutritives naturelles. Dans le réservoir, le gobie demi-lune a développé une importante population colonisant les berges enrochées. Son régime alimentaire est exclusivement d'origine ani- male avec une dominance significative et une préférence pour deux sources

(1) University of South Bohemia, Faculty of Fisheries and Protection of Waters, Zátiši 728/II, 38925 Vodňany, Czech Republic, adamek@ivb.cz

(2) Institute of Vertebrate Biology Academy of Sciences of the Czech Republic, v.v.i., Květná 8, 60365 Brno, Czech Republic

(3) Department of Zoology, Fisheries, Hydrobiology and Apiculture, Mendel University of Agriculture and Forestry, Nejdecká 600, 69144 Lednice na Moravě, Czech Republic 
alimentaires - les larves de chironomes (Chironomidae) et les Aselles (Asellus aquaticus) qui contribuent respectivement pour 40,2 et 27,6 \% au bol alimentaire ingéré. L'indice de prépondérance pour ces deux types d'aliments est très élevé, respectivement 73,8 et 26,5 . Au cours de l'année, une préférence remarquable pour les larves de chironomides est enregistrée en été alors que les Aselles sont consommées majoritairement en hiver. La proportion des autres types d'aliment était assez marginale - seulement des corixidés, copépodes, cératopogonides et cladocères ont une certaine importance avec une contribution de 5,4; 4,3; 4,1 et $3,9 \%$ respectivement. Quelques signes de cannibalisme sont aussi notés avec 0,9 et $0,2 \%$ du bol alimentaire représenté par sa propre progéniture et des œufs respectivement.

\section{INTRODUCTION}

Tubenose goby, Proterorhinus semilunaris (Pallas, 1811), is a small benthic fish (max. $10 \mathrm{~cm}$ long) occupying both lotic and lentic waters. Tubenose gobies have been found in places with dense aquatic vegetation, gravel-sand beaches and stony rip-rap (Lelek, 1987; Baruš and Oliva, 1995).

Originally, tubenose gobies, Proterorhinus marmoratus, were generally supposed to occupy basins of the Black, Caspian and Azov Seas inhabiting salt and brackish water, and they were also supposed to live permanently in freshwater in the Danube, Bug, Dnieper, Don, Donets and Kuban rivers (Lelek, 1987). However, according to genetic evaluation (Stepien and Tumeo, 2006), the existence of the two species was validated, $P$. semilunaris as a freshwater species and $P$. marmoratus as a marine one. In the Danube River watershed, tubenose goby was registered for a long time as far west as Neusiedler Lake in Austria and in the Danube River tributaries - the Váh, Nitra and Morava rivers - on the Slovak territory. Recently, it has been registered in the whole Austrian (Ahnelt, 1988) - Bavarian stretch of the Danube River (Reinartz et al., 2000). In 1997, the tubenose goby was registered in River Main near Eltmann where it penetrated via the Rhine-Main-Danube canal (Reinartz et al., 2000). Its expansion in this direction has continued recently in the Rhine on the territory of France (Manné and Poulet, 2008). In the Morava River (the Danube tributary from the Czech territory), tubenose goby was first recorded by Koelbel (1874), near the mouth into the Danube. This site has been for a long time the only locality of tubenose goby occurrence in the Morava River. In the nineties, the tubenose goby slowly commenced to spread upstream up to $41 \mathrm{r}$. km of the Morava River near the village of Gajary (Slovakia) (Spindler et al., 1992; Prášek and Jurajda, 2005).

The tubenose goby has never been mentioned in the historical sources of the Czech fish fauna (Heinrich, 1856; Jeitteles, 1863, 1864; Hykeš, 1921; Dyk, 1946; Oliva, 1956; Kux, 1957). Its occurrence in the Czech Republic (11 specimens) was recorded for the first time in spring 1994 in the upper Mušov reservoir (528 ha) of the system of Nové Mlýny Water Reservoirs. They were revealed in the stony rip-rap bank near the village of Pasohlávky, far away $(95.5 \mathrm{~km})$ from the nearest marginal site of the original distribution area (Lusk and Halačka, 1995). The most presumable origin of these fish seems to be the transfer and subsequent release as baitfish by the anglers arriving from Danubian countries. In the following years, tubenose goby occupied the whole lower Dyje River $(84 \mathrm{~km})$ and became a dominant species in the shoreline assemblage. Its fast expansion downstream of the reservoirs to the river between the new and original sites of occurrence was supported by the drift of juvenile stages through the power plant in the lowest dam (Kružíková et al., 2003) and probably also by the flood discharge in summer 1997. At present, tubenose goby has been spread regularly in the lower Dyje and Morava rivers and their tributaries (Lusk et al., 2000; Švátora et al., 2000), including various water bodies in their basins such as ponds and their connecting channels (Chaloupková and Adámek, 2009). The detailed description of its expansion commencement in the Czech Republic was published by Prášek and Jurajda (2005).

The first published data on food and food preference of tubenose goby in the native area of its distribution was provided by Shorygin (1939), who concluded that crustaceans are 
the most commonly consumed food item. According to recent data from Central Europe (the Hron River, Slovakia), chironomid larvae and pupae strongly predominated in the diet of tubenose goby (Adámek et al., 2007). Ghedotti et al. (1995) noted that tubenose gobies feed on small crustaceans and aquatic insect larvae, while Charlebois et al. (1997) and French and Jude (2001) reported that crustaceans (amphipods and isopods), dipteran and mayfly larvae (Caenis) and ostracods were the dominant food items of the tubenose goby in the non-native area in the St. Clair basin (North America).

The objective of this study was to evaluate the annual pattern of tubenose goby feeding habits in the newly colonised habitats of the Mušov reservoir on the Dyje River (the Danube basin, Czech Republic) with respect to natural food resources.

\section{MATERIALS AND METHODS}

\section{$>$ THE STUDY AREA}

The lowland Nové Mlýny reservoir system (161-171 m above sea level) was built on the Dyje River (the Danube basin) in south Moravia, Czech Republic, during the years 1975-1989. The reservoir system consists of three reservoirs - Mušov (area 528 ha, max. depth $4.3 \mathrm{~m}$, operated since 1979), Věstonice (1031 ha, 5.2 m, 1982) and Nové Mlýny (1668 ha, 7.7 m, 1989). By their morphology, the reservoirs rather resemble large carp ponds (low depth, eutrophic environment) under climatic conditions promoting high productivity. The majority of shoreline of the reservoirs is man-made (stony rip-rap, concrete stepped embankment) with the exception of some sand-gravel beaches. For a detailed description of the study area see, e.g., Pellantová and Franek (1994).

The fish assemblage of the Mušov reservoir has been studied quite frequently, commencing since the period of its filling (Lusk, 1984; Adámek et al., 1985; Jirásek and Adámek, 1986).

\section{$>$ METHODS}

Fish sampling was carried out monthly at the Mušov reservoir (48 $\left.53^{\prime} 12^{\prime \prime} \mathrm{N}, 16^{\circ} 34^{\prime} 37^{\prime \prime} \mathrm{E}\right)$ in January-November. Altogether, 1537 individuals of the tubenose goby were captured. Besides tubenose goby, 86, 7 and 1 individuals of perch (Perca fluviatilis), ruffe (Gymnocephalus cernuus) and topmouth gudgeon (Pseudorasbora parva), respectively, were captured in the stony rip-rap banks. Among fish randomly selected for food analyses, 16 stomachs were empty and so for the evaluation a final total of 314 individuals were examined (Table I). Due to the weather conditions (thick ice cover at the sampling sites) samples could not be collected in December.

Examined fish were collected from the rip-rap littoral zone of the Mušov reservoir using electrofishing gear (backpack type LENA, 220-240 V, 1.5-2 A, 80-90 Hz). Immediately after catching, examined fish were killed with an overdose of the anaesthetic clove oil and preserved in $4 \%$ formaldehyde. Fish were measured and weighed to the nearest $\mathrm{mm}$ and $0.01 \mathrm{~g}$, respectively, after three months of storage. Their digestive tracts were weighed with the food immediately after removal, then dissected and weighed again to derive the food weight. Digestive tract contents were identified to the lowest feasible taxonomic group (family, genus and/or, when possible, species). The percentage contribution by weight of each food item was estimated (Hyslop, 1980) as a relative weight percentage $\left(\% W_{i}\right)$, which was subsequently recalculated as

$$
\% W_{i}=100 \cdot\left(W_{i} / \sum_{i=1}^{n} W_{\mathrm{t}}\right),
$$

where $n=$ total number of prey items and $W_{i}=$ wet weight of prey item $i$ and $W_{t}=$ total weight of digestive tract contents in the entire monthly sample. 


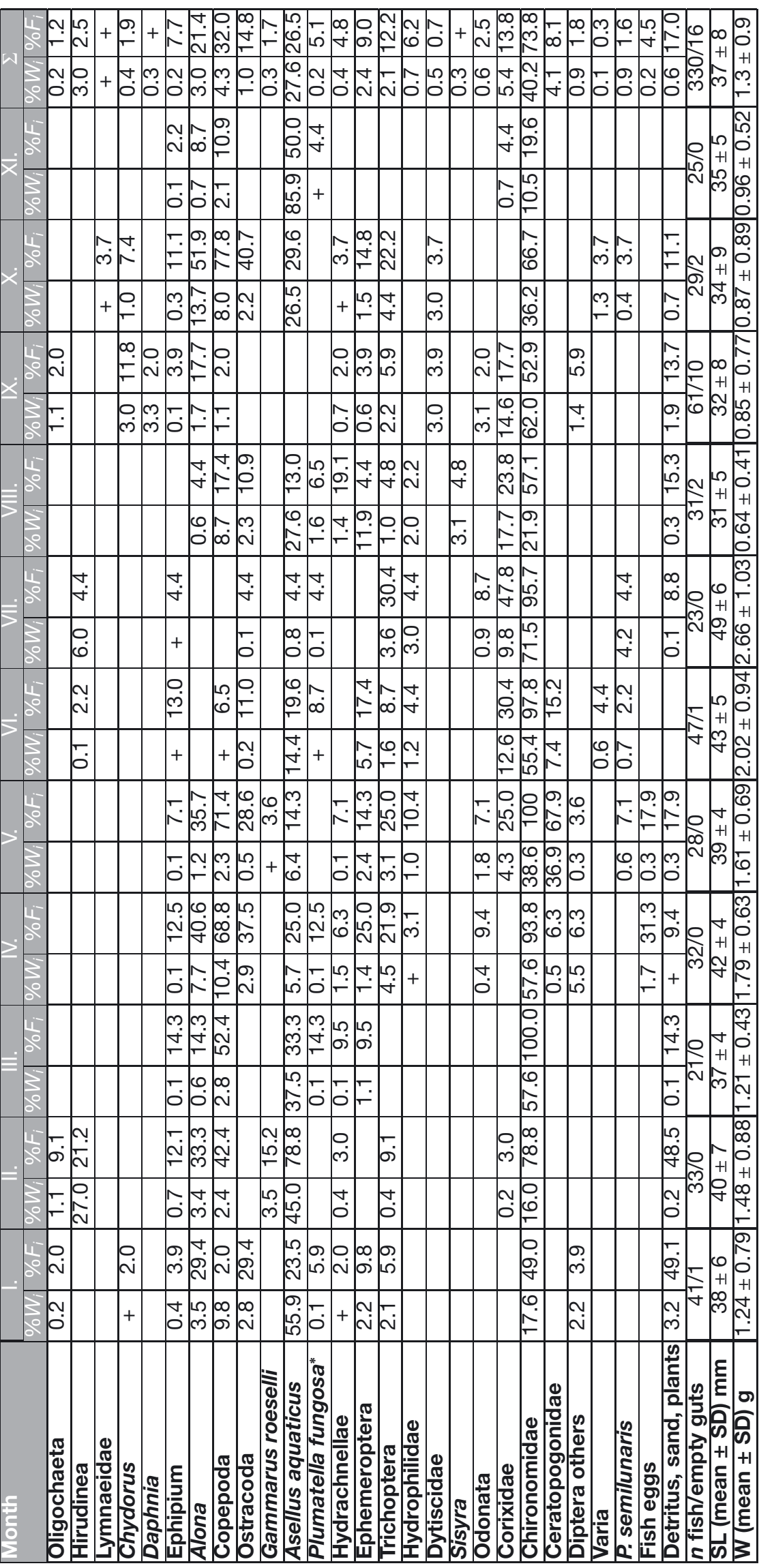


The percentage (frequency) of occurrence $\left(\% F_{i}\right)$ was defined as the percentage of digestive tracts containing the food item $i$. It is described by the equation

$$
\% F_{i}=100 \cdot\left(n_{i} / n\right),
$$

where $n_{i}$ is the number of fish with food item $i$ in their digestive tract and $n$ is the total number of fish with digestive tract contents. Fish with empty digestive tracts were not taken into account.

Food bulk weight was assessed to the nearest $\mathrm{mg}$ and presented as the index of gut fullness $(I F)$ in $\%$ ooo. It was calculated as a ratio between food $(w)$ and fish $(W)$ weights:

$$
I F=10^{4} \cdot(w / W) .
$$

Costello's (1990) graphical method, as modified by Amundsen et al. (1996) was applied for the interpretation of the role of particular food items in the diet of the fish examined. It enables prey importance and feeding strategy to be explored and presented graphically. The new precise approach of Amundsen et al. (1996) is based on the substitution of percentage abundance by prey-specific abundance $\left(P_{i}\right)$, which is defined by the equation

$$
P_{i}=100 \cdot\left(\sum S_{i} / \sum S_{t}\right) \text {, }
$$

where $S_{i}=$ the digestive tract content (by weight) comprised of prey species $i$ and $S_{t}=$ the total digestive tract content in only those fish with prey species $i$ in their digestive tracts.

The grading of particular food item i's importance was performed using the index of preponderance $\left(I_{P_{i}}\right)$ by Natarajan and Jhingran (1961) as

$$
I_{\mathrm{P}_{i}}=\left(\% W_{i} \% F_{i}\right) /\left(\sum \% W_{i} \% F_{i}\right) \cdot 100,
$$

where $\% W_{i}=$ weight percentage of food item $i$ and $\% F_{i}=$ percentage of occurrence of food item $i$. This index classifies individual food items according to their importance in the diet of the given species.

With respect to the habitat character (large boulders $0.5-1 \mathrm{~m}$ on average), the samples of food supply (benthic invertebrates) were collected semi-quantitatively by 1 -min sweep net sampling nearby and amongst the boulders. Using the data on food supply composition, Ivlev's selectivity coefficient (Jacobs, 1974) was applied for the evaluation of food electivity:

$$
E=(r-p) /(r+p),
$$

where $r$ = percentage of a certain food item taken by fish, $p=$ percentage of that prey item available in the environment. Thus, a value of $E=0.00$ means that the consumption of a particular food item corresponds to its occurrence, whilst $-1<E<-0.01$ and $0.01<E<1$ indicate negative (lesser consumption than expected from estimates of food item abundance) and vice versa positive selectivity for a particular food item, respectively.

To compare the differences in the seasonal food intake we divided the year into four seasons, winter (I-II), spring (III-V), summer (VI-VIII) and autumn (IX-XI). Analysis of variance (ANOVA; Scheffe post-hoc test) was applied to test the differences between the index of filling in particular seasons and months. The differences in food composition were evaluated using the Kruskal-Wallis test (K-W; Multiple Comparison of Mean Ranks - MCMR post-hoc test).

\section{RESULTS}

The most commonly consumed food item in the Mušov reservoir was chironomid larvae (Chironomidae - Phytotendipes gripekoveni in particular), with a year-round proportion of $40.2 \%$ (Table I). The second most significant food component was the waterlouse (Asellus aquaticus) with a proportion of $27.6 \%$. Aside from these two predominating items of the diet, 


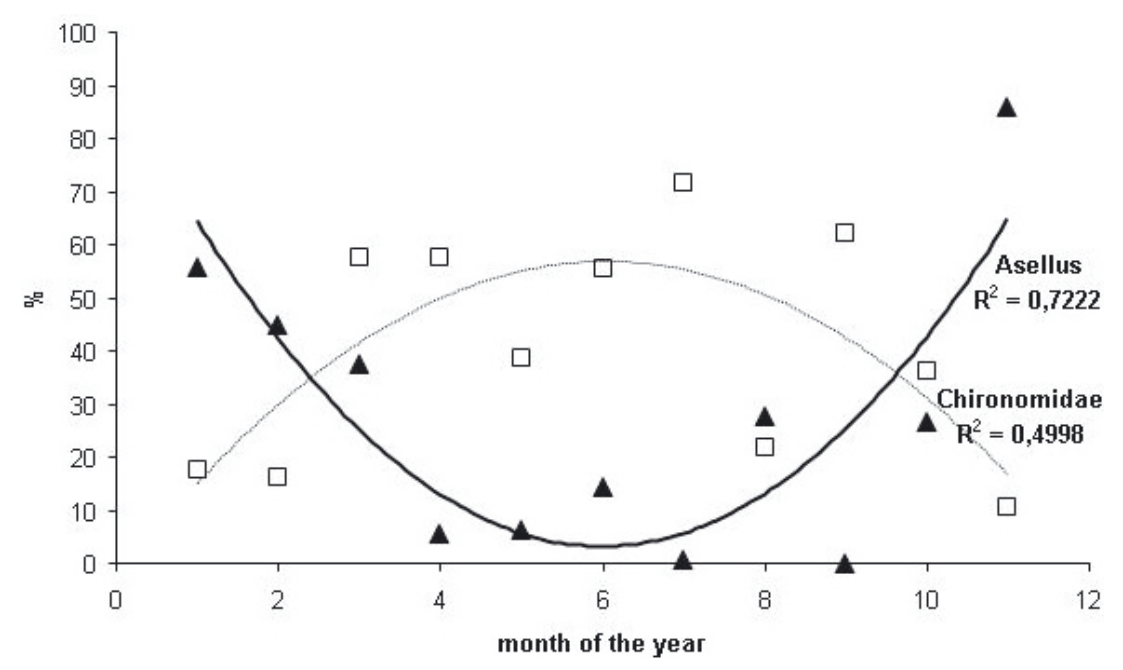

Figure 1

Proportion and trends of dominant food items' (Asellus and chironomids) importance in the tubenose goby diet during the year.

\section{Figure 1}

Proportions et tendances des proies dominantes (Asellus et chironomides) dans l'alimentation du gobie demi-lune au cours d'une année.

there were some other items of lesser importance such as water bugs (Corixidae), copepods (Copepoda), ceratopogonids (Ceratopogonidae), cladocerans (Cladocera) and leeches (Hirudinea), appearing in diets at rates of 5.4, 4.3, 4.1, 3.9 and 3.0\%, respectively. Lastly, the presence of mayfly nymphs (Ephemeroptera) and caddis fly larvae (Trichoptera) was recorded, with respective proportions of 2.4 and $2.1 \%$ in the tubenose goby diet. Mayfly nymphs were represented by Baetis sp., Caenis sp. and Cloeon dipterum and caddis fly larvae belonged to Neureclipsis bimaculata and Holocentropus dubius. The other food items were of minor importance and did not exceed the level of $1.0 \%$ proportion of the total food bulk.

Tubenose goby juveniles (and very probably also their eggs) appeared in several food samples in May-July (exceptionally also in October) and April-May, respectively (Table I).

In dominating food items, their monthly frequency of occurrence ranged between $20-100 \%$ for chironomids (73.8\% during the whole year), and between 0-79\% (26.5\%) for Asellus. In terms of seasonal differences, chironomids were prevalent in spring and summer, with the rate of biomass 21.9 to $71.5 \%$ and frequency of occurrence 57 to $100 \%$. Their significantly $(P<0.001$, K-W post-hoc MCMR) higher percentage was proved in March-July compared with January-February and August-November. The second most common food item, Asellus aquaticus, gained significance during autumn and winter with the maximum rates of food biomass and frequency of occurrence 85.9 and $78.8 \%$, respectively (Table I, Figure 1). The $\mathrm{K}-\mathrm{W}$ (post-hoc MCMR) test revealed significantly higher $(P<0.001)$ consumption of Asellus in January, February and November compared with the period of March-October. Despite higher figures of corixid percentage in June-September, no significant differences $(P>0.05)$ were proved between the months of the growing season. However, their occurrence (Table I) was either zero or very sporadic during the remaining periods of the year (January-April and October-November).

Copepods and cladocerans occurred regularly, with a few exceptions, during the course of the year at respective maximum 10.4 and $14.0 \%$ food weight proportion, and 77.8 and $51.9 \%$ frequency of occurrence. Consumed cladocerans belonged to the Chydorus, Alona and Daphnia genera, including ephipia of daphniids, which were found on a regular basis except for August at the frequency of occurrence 2.2-14.3\%.

Food composition and the presence of individual components were manifested in the index of preponderance $\left(I_{\mathrm{P}}\right)$, demonstrating that the most important item of the tubenose goby 


\section{Table II}

Index of preponderance $\left(I_{\mathrm{P}}\right)$ and index of selectivity $(E)$ of main food groups in the tubenose goby diet in Jan.-Nov. 1998 (mean values for the whole period under study). Note: * absent in the diet; ${ }^{* *}$ absent in food resources, - irrelevant.

\section{Tableau II}

Indice de prépondérance $\left(I_{P}\right)$ et indice de sélectivité $E$ des principaux types d'alimentation du gobie demi-lune de janvier à novembre 1998 (valeurs moyennes pour toute la période d'étude). Note : * absent dans l'alimentation; ** absent dans les ressources alimentaires; - sans objet.

\begin{tabular}{|c|c|c|}
\hline Food item & $I_{p}$ & $E$ \\
\hline Hydra* & & - \\
\hline Turbellaria* & & - \\
\hline 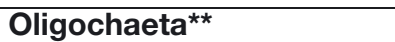 & 0.02 & - \\
\hline Hirudinea & 0.03 & -0.60 \\
\hline Lymnaeidae & + & - \\
\hline Cladocera & 2.18 & +0.82 \\
\hline Copepoda & 3.36 & +0.88 \\
\hline Ostracoda ${ }^{* *}$ & 0.47 & - \\
\hline Gammarus roeselit ${ }^{\star *}$ & 0.09 & - \\
\hline Asellus aquaticus & 24.98 & +0.75 \\
\hline Plumatella fungosa & 0.04 & - \\
\hline Hydrachnellae & 0.12 & -0.99 \\
\hline Ephemeroptera & 0.50 & +0.96 \\
\hline Trichoptera & 0.61 & +0.57 \\
\hline Corixidae & 3.08 & +0.04 \\
\hline Coleoptera I. aquat. & 0.05 & +0.58 \\
\hline Sisyra** & 0.06 & - \\
\hline Odonata $^{* *}$ & 0.04 & - \\
\hline Chironomidae & 58.81 & +0.43 \\
\hline Ceratopogonidae & 4.95 & +0.99 \\
\hline Proterorhinus semilunaris & 0.03 & - \\
\hline Fish eggs & 0.08 & - \\
\hline
\end{tabular}

diet was chironomids $\left(I_{P}=58.81\right)$ followed by Asellus, ceratopogonids and copepods with $I_{\mathrm{P}}=24.98,4.95$ and 3.36 , respectively (Table II). Essentially, all significant items with a proportion higher than $0.05 \%$ were positively selected, meaning that their proportion in the tubenose goby diet was higher than their natural occurrence in the surrounding environment. By contrast, the only refused food components were hydras, turbellarians, water snails (Lymnaeidae) and water mites (Hydrachnellae).

The food strategy as presented by Costello's (1990) approach with Amundsen's (1996) modification revealed chironomid larvae as the dominant food item. Leeches (Hirudinea), waterlouse (Asellus aquaticus) and ceratopogonid larvae are to be considered as food consumed just occasionally in bigger amounts by some fish individuals (specialisation - Figure 2). Remaining food items occurring in the tubenose goby diet belonged rather among rare food resources.

The intensity of food intake (Figure 3 ) expressed as the intensity of gut fullness (IF) was highest in spring, particularly in May $(426 \pm 341 \% 00)$, and lowest in July ( $89 \pm 49 \% 00)$. Both monthly May and July mean values differ significantly $(P<0.05)$ from all (May) or from the majority (July) of other mean monthly values all the year around. Mean IF values corresponded to $151 \pm 142,228 \pm 161,161 \pm 195$ and $188 \pm 241 \%$ oo in winter, spring, summer and autumn periods, respectively, with significantly $(P<0.05)$ higher spring values.

\section{DISCUSSION}

The tubenose goby diet was exclusively of animal origin, predominantly zoobenthos. Particles of detritus, sand, etc., were occasionally recorded in the stomach content $(0.6 \%$ of food biomass), ingested very probably as a "by-catch" with food animals. 


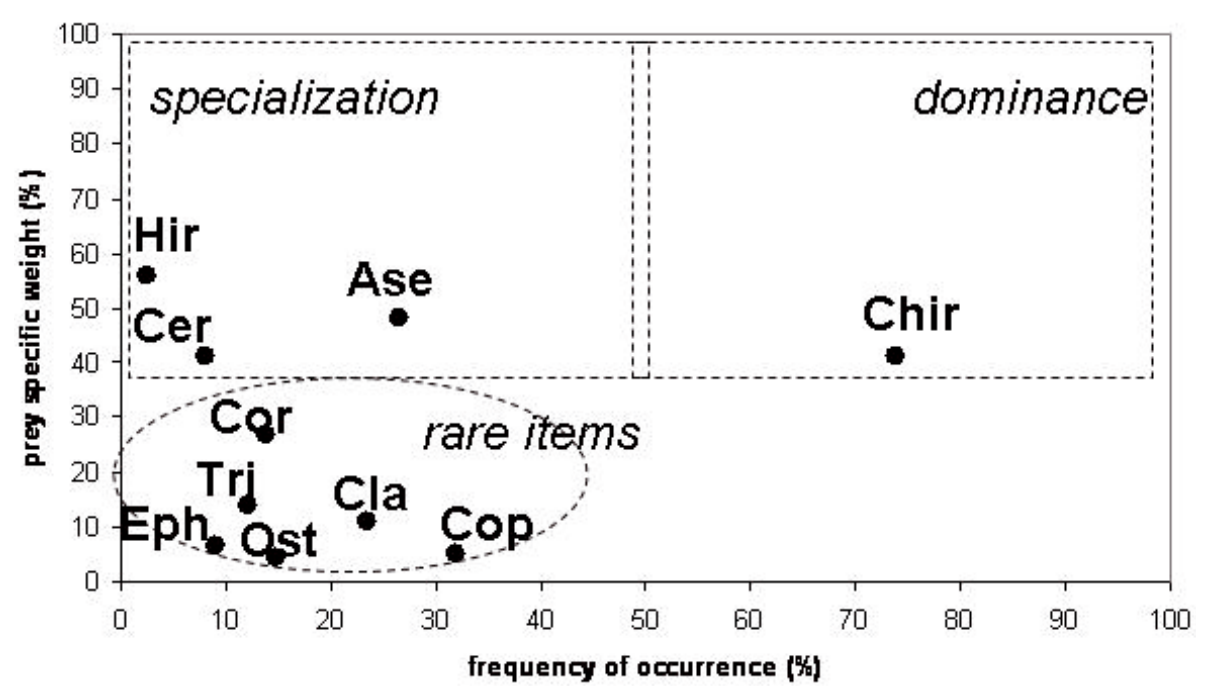

\section{Figure 2}

Costello's (1990) graphical interpretation, using Amundsen et al.'s (1996) modification, of the role of the most important food items of tubenose goby in the Mušov Resevoir. Note: Hir - Hirudinea, Cla Cladocera, Cop - Copepoda, Ost - Ostracoda, Ase - Asellus aquaticus, Cor - Corixidae, Eph Ephemeroptera, Tri - Trichoptera, Chir - Chironomidae, Cer - Ceratopogonidae.

Figure 2

Interprétation graphique de Costello (1990), avec modification selon Amundsen et al. (1996) du rôle des principales proies du gobie demi-lune dans le réservoir Mušov. Abréviations : Hir - Hirudinea, Cla - Cladocera, Cop - Copepoda, Ost - Ostracoda, Ase - Asellus aquaticus, Cor - Corixidae, Eph Ephemeroptera, Tri - Trichoptera, Chir - Chironomidae, Cer - Ceratopogonidae.

ce

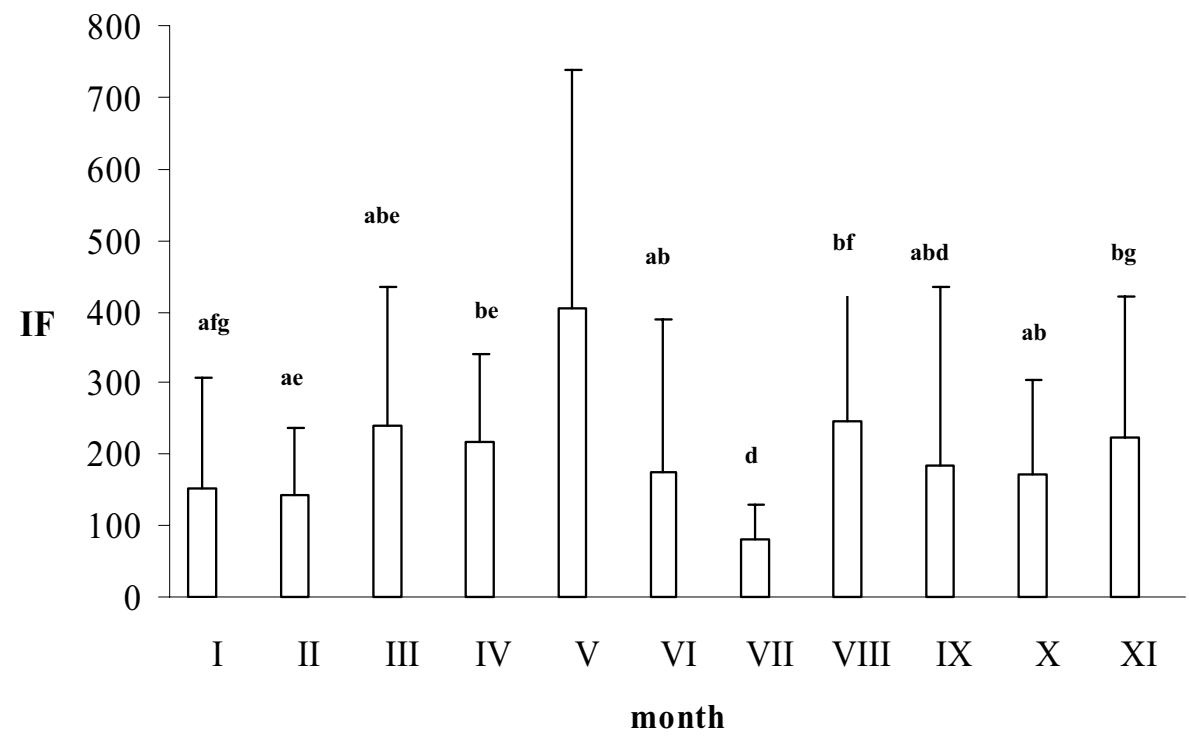

Figure 3

Annual course of the index of tubenose goby gut fullness (IF). Note: Abscissas indicate significant difference. Columns with different superscripts are significantly different at $P<0.05$.

\section{Figure 3}

Variation mensuelle de l'indice de remplissage stomacal du gobie demi-lune (IF). Note : les différentes lettres signifient une différence significative entre IF mensuels à $P<0,05$. 
Chironomid larvae, which are a very common part of zoobenthos, take the most important position in the diet of tubenose goby as a food generalist. In the littoral zone of the Mušov reservoir, chironomids accounted for the majority of the macrozoobenthos and comprised up to $71.5 \%$ to the tubenose goby diet. Amongst them, Phytotendipes gripekoveni and Orthocladiinae g.sp., were the most common, appearing periodically in the tubenose goby diet with the average frequency of occurrence of 73.7 and $40.3 \%$, respectively. These high values led naturally to high indices of chironomid preponderance $\left(I_{P}=58.81\right)$ and selectivity $(E+0.43)$. Chironomid larvae are also mentioned as a dominant part of the diet in the food generalist tubenose goby by some other authors (French and Jude, 2001; Adámek et al., 2007). Ceratopogonid larvae, which are quite similar to chironomids, were also an important food item with $I_{\mathrm{P}}=4.95$ and a very high positive index of selectivity $(E+0.99)$.

The second most common food component was the isopod crustacean - waterlouse Asellus aquaticus, comprising $27.6 \%$ of the food intake at $26.5 \%$ frequency of occurrence. In comparison with the natural food offer, Asellus was highly selected $(E+0.75)$ and its overall importance was also very high $\left(I_{P}=24.98\right)$, particularly in the cold period of the year when its proportion of the total food bulk ranged between 37.5 and $85.9 \%$ in March and November, respectively. Isopods are also mentioned as an important part of the tubenose goby diet in other studies (Ghedotti et al., 1995; Charlebois et al., 1997; French and Jude, 2001).

Despite the occurrence of corixids, cladocerans and copepods, which are generally considered as nektonic and/or planktonic (rarely also benthic) invertebrates, the feeding habits of tubenose goby are to be considered as benthivorous. Interstitial areas in stony rip-rap banks provide a very favourable and safe environment for both corixids and planktonic (Chydorus, Daphnia, Cyclopoida) and benthic (Alona, Harpacticoida, Asellus aquaticus) crustaceans so they are readily available to gobiids which share the same space with them. These food invertebrates were, when compared with their occurrence, positively selected with the values of $E+0.04,+0.82$ and +0.88 for corixids, cladocerans and copepods, respectively.

According to analyses of the selectivity for food items of animal origin present at the study sites, it is clear that the tubenose goby positively selected all important food invertebrates, with the exception of water mites (Hydrachnellae) and animals more or less attached to the substrate, such as hydras (Hydrozoa - Hydra sp.), turbellarians (Turbellaria - Planaria tigrina, P. polychroa), leeches (Hirudinea - Erpobdella octoculata, Helobdella stagnalis, Glosiphonia complanata) and water snails (Gastropoda - Valvata piscinalis, Bithynia tentaculata, Physa sp., Lymnaea sp., Planorbis sp.). These invertebrates were recorded in the samples of available food but not in the tubenose goby diet. On the contrary, despite being absent in samples of food resources, ostracods and dragonfly nymphs appeared sporadically in the food bulk of the tubenose goby.

The presence of fertilised fish eggs and fry (including their own progeny) in the diet, as speculated by Bănărescu (1964), was confirmed, although the importance of these food components $\left(I_{P}=0.03\right.$ and 0.08 for fry and eggs, respectively) is considered as rather insignificant.

According to the whole year of study, tubenose goby fed continuously during the year, including winter (Figure 3$)$. There was a certain significant $(P<0.05)$ increase in feeding intensity prior to and at the beginning of the spawning season (May), whereas during the actual spawning (June) a distinct decline in IF was evident. Nevertheless, the whole spring period is to be considered as a period of significantly $(P<0.05)$ increased food intake in comparison with other seasons of the year. The variability in the food intake related to the biological traits of the species - increased food intake corresponded to reproduction onset, while the steep decrease apparently followed afterwards with the actual spawning and subsequent guarding of the eggs by males. Despite slightly decreased winter IF values, non-significant differences between summer and winter $(P>0.05)$ IF values indicated a remarkable food intake during the cold period of the year. Another factor which possibly might affect the food intake pattern was a frequently recorded gut infestation by acanthocephal Apatemon cobitidis proterorhini. However, as documented by Adámek and Obrdlík (1977), the intensity of infestation by acanthocephales and nematodes did not affect the indices of alimentary tract fullness in chub 
(Leuciscus cephalus) and barbel (Barbus barbus), and it is likely they do not impact considerably upon food ingestion in tubenose goby as well.

Tubenose goby is considered as an alien fish species in Central Europe. It is continuously spreading upstream of the Danube and its tributaries. The interactions between tubenose goby and native fish species concern mainly competition for space and food. Due to its specific habitat preferences - occupation of various-sized shelters in stony littoral habitats the competition between tubenose goby and the majority of native fish occurring in the Mušov reservoir for space can be considered as rather negligible. The co-existence of other fish species (perch, ruffe and topmouth gudgeon) in the stony rip-rap was quite rare and they constituted only $5.8 \%$ of the total catch recorded by electrofishing sampling.

Food competition seems to be more obvious since a remarkable coincidence for the dominant food items can be observed in tubenose goby and other fish species. Chironomids, which constitute the dominant part $(58.81 \%)$ of the tubenose goby diet, are also regularly ingested by some percids and cyprinids. Chironomids were found to contribute $28.81 \%$ to the diet of perch originating from the same sampling events. On the other hand, tubenose goby became a dominant food item of perch, composing $40.59 \%$ of the food bulk (Jurajda et al., in prep.). This means that perch are able to penetrate into the interstitial rip-rap space when searching for prey (tubenose goby and chironomids). Food coincidence resulting probably from identical food habitats concerned the majority of food items - cladocerans ( 3.9 and $5.5 \%$ in tubenose goby and perch, respectively), copepods (4.3 and 3.3\%), ceratopogonids (4.1 and $1.4 \%$ ) and corixids (5.4 and 2.9\%). Surprisingly, no waterlouse (Asellus), constituting $27.6 \%$ of the tubenose goby diet, were noticed in the diet of perch despite the fact that it is considered as its regular and preferred prey (e.g. Adámek et al., 2006). The food coincidence between tubenose goby and cyprinid fish species was not so remarkable and concerned mainly cladocerans in roach, Rutilus rutilus, rudd, Scardinius erythrophthalmus, white bream, Blicca bjoerkna, and common bream, Abramis brama and chironomids in common carp, Cyprinus carpio. The intensity of possible competition is, however, certainly significantly reduced by different feeding habits and habitat preference in $>1+$ cyprinids, which usually do not regularly enter the interstitial rip-rap spaces.

\section{ACKNOWLEDGEMENTS}

This study was supported by the USB RIFCH projects no. MSM 6007665809, MSM 6215648905 and Centre of Excellence (LC 522) of the MSMT CR.

\section{REFERENCES}

Adámek Z. and Obrdlík P., 1977. Food of important cyprinid species in the warmed barb zone of the Oslava River. Fol. Zool., 26, 171-182.

Adámek Z, Jirásek J., Pravda D., Sukop I., Heteša J., Provázek R. and Škrabánek A., 1985. Food biology and biological value of roach (Rutilus rutilus) in the Mušov reservoir. Živ. výr., 30, $901-910$ (in Czech).

Adámek Z., Jurajda P., Musil J., Janáč M., Kabilka P., Polačik M., Ťuk J., Valová Z. and Zeman J., 2006. Perch (Perca fluviatilis) diet during the flooding period of the Chabařovice coal mining pit (NorthWest Bohemia, Czech Republic). In: The 5th International Conference on Reservoir Limnology and Water Quality, Brno, 67-68.

Adámek Z., Andreji J. and Martín Gallardo J., 2007. Food habits of four bottom-dwelling gobiid species at the confluence of the Danube and Hron Rivers (South Slovakia). Internat. Rev. Hydrobiol., 92, 554-563.

Ahnelt H., 1988. Zum Vorkommen der Marmorierten Grundel (Proterorhinus marmoratus (Pallas), Pisces: Gobiidae) in Österreich. Ann. Naturhist. Mus. Wien, 90 B, 31-42.

Amundsen P.A., Gabler H.M. and Staldvik F.J., 1996. A new approach to graphical analysis of feeding strategy from stomach contents data - modification of the Costello (1990) method. J. Fish Biol., 48, 607-614. 
Bănărescu P., 1964. Fauna Republicii Populare Romine. Pisces - Osteichthyes, Ed. Acad. RPR, Bucharest, 962 p. (in Romanian).

Baruš V. and Oliva O., 1995. Lampreys - Petromyzontes and Fish - Osteichthyes 2, Academia, Praha, 698 p. (in Czech).

Chaloupková L. and Adámek Z., 2009. Fish assemblages in the canals of the Nesyt and Vrkoč pond systems (South Moravia, Czech Republic). In: 60th Anniversary of Fisheries Education at MZLU Brno, MZLU, Brno, 131-137 (in Czech).

Charlebois P.M., Marsden J.E., Goettel R.G., Wolfe R.K., Jude D.J. and Rudnicka S., 1997. The round goby, Neogobius melanostomus (Pallas), a review of European and North American literature, Illinois-Indiana Sea Grant Program and Illinois Natural History Survey. INHS Special Pub., 20, 61 p.

Costello M.J., 1990. Predator feeding strategy and prey importance: new graphical analysis. J. Fish Biol., 36, 261-263.

Dyk V., 1946. Our Fishes, SPN Praha, 339 p. (in Czech).

French III J.R.P. and Jude D.J., 2001. Diets and diet overlap of nonindigenous gobies and small benthic native fishes co-inhabiting the St. Clair River, Michigan. J. Great Lakes Res., 27, 300-311.

Ghedotti M.J., Smihula J.C. and Smith G.R., 1995. Zebra mussel predation by round gobies in the laboratory. J. Great Lakes Res., 21, 665-669.

Heinrich A., 1856. Mährens und k. k. Schlesiens Fische, Reptilien und Vögel. Ein Beitrag zur Fauna beider Kronländer, Brno, $200 \mathrm{p}$.

Hykeš O., 1921. Fishes of the Czech Republic. Čas. musea král. Českého, odd. prír., Praha, 95, 89-105 (in Czech).

Hyslop E.J., 1980. Stomach content analysis - a review of methods and their application. J. Fish. Biol., 17, 411-429.

Jacobs J., 1974. Quantitative measurements of food selection. A modification of the forage ratio and Ivlev's electivity index. Oecologia, 14, 413-417.

Jeitteles L.H., 1863. Die Fische der March bei Olmütz. Jahresbericht über das k. k. Gymnasium in Olmütz während des Schuljahres 1863, 3-33.

Jeitteles L.H., 1864. Die Fische der March bei Olmütz. II. Jahresbericht über das k. k. Gymnasium in Olmütz während des Schuljahres 1864, 3-26.

Jirásek J. and Adámek Z., 1986. The development of biological conditions on the Mušov and Věstonice Reservoirs in 1981-84. Folia Univ. Agr., 71 p. (in Czech).

Koelbel C., 1874. Über die Identität der Gobius semilunaris Heck und G. rubromaculatus Kriesch mit G. marmoratus Pallas. Verh. K.-k. zool.-bot. Ges. Wien, 269-574.

Kružíková L., Jurajda P. and Prášek V., 2003. Passage of the $0+$ juvenile fishes through small water plant of Nové Mlýny water reservoirs. In: Bryja J. and Zukal J. (eds.), Zoologické dny Brno, Proc. of a Conference, 114-115 (in Czech).

Kux Z., 1957. A contribution to the knowledge of fish assemblage in the Danube River catchment area in the Czech Republic. Čas. Mor. muzea, Brno, 42, 67-84 (in Czech).

Lelek A., 1987. Threatened Fishes of Europe - The Freshwaters Fishes of Europe, 9, AULA-Verlag, Wiesbaden.

Lusk S., 1984. Fisheries management of the upper reservoir of the Nové Mlýny Reservoirs on the Dyje River. Živ. výroba, 29, 1043-1051.

Lusk S. and Halačka K., 1995. The first finding of the tubenose goby, Proterorhinus marmoratus, in the Czech Republic. Folia Zool., 44, 90-92.

Lusk S., Lusková V., Halačka K. and Lojkásek B., 2000. Changes in species diversity of fish assemblages on the teritorry of the Czech Republic after 1990. In: Biodiverzita ichtyofauny ČR (III), 21-28 (in Czech).

Manné S. and Poulet N., 2008. First record of the western tubenose goby Proterorhinus semilunaris (Haeckel, 1837) in France. Knowl. Managt. Aquatic Ecosyst., 389, 03.

Natarajan A.V. and Jhingran A.G., 1961. Index of preponderance - a method of grading the food elements in the stomach analysis of fishes. Indian J. Fish., 8, 54-59.

Oliva O., 1956. Contributions to systematic revision of some our fishes, part II. Čas. Nár. muzea Praha, 124, 171-182 (in Czech). 
Pellantová J. and Franek M., 1994. Research for the Nové Mlýny reservoirs area for the period 1988-1993. Proceedings Czech Institute of Nature Protection, Praha, 182 p. (in Czech).

Prášek V. and Jurajda P., 2005. Expansion of Proterorhinus marmoratus in the Morava River basin (Czech Republic, Danube R. watershed). Folia Zool., 54, 189-192.

Reinartz R., Hilbrich T. and Born O., 2000. Nachweis der Marmorierten Grundel (Proterorhinus marmoratus Pallas, 1811) im unterfraenkischen Main bei Eltmann (Rheineinzugssgebiet). Österreichs Fischerei, 53, 192-194.

Shorygin A.A., 1939. Food and food preference of some Gobiidae of the Caspian Sea. Zool. Zh., 18, 27-53.

Spindler T., Holčík J. and Hensel K., 1992. Die Fischfauna der österreichisch - tschechoslowakischen Grenzstrecke der March samt inrem Einzugsgebiet. Bericht 5/1992, Forschungsinstitut WWF Österreich, $179 \mathrm{p}$.

Stepien C.A. and Tumeo M.A., 2006. Invasion genetics of Ponto-Caspian gobies in the Great Lakes: a 'cryptic' species, absence of founder effects, and comparative risk analysis. Biol. Invasions, 8 , 61-78.

Švátora M., Křižek J. and Reiter A., 2000. Fish assemblage of the upper Dyje - Bílý Kř́iž. In: Biodiverzita ichtyofauny ČR (III), Brno, 161-164 (in Czech). 